\title{
1. Judges and technology
}

\section{INTRODUCTION}

In the years leading up to 2020, many of the processes used by judges around the world reflected those that had been used by judges for decades. Although there were a number of judicial and court outliers, ${ }^{1}$ often judges and courts relied on paper-based and in-person oral exchanges with limited use of technology. ${ }^{2}$ If they did not rely on these operational modes, technological advances tended to mimic or reflect existing paper-based and in-person approaches.

However, by 2020 some courts had begun to operate in quite different ways and had integrated Online Dispute Resolution (ODR) features into their activities, digitized records, enabled paperless e-filing systems and begun to develop new ways of engaging with people that were supported by technology. Courts adopting such approaches were sometimes referred to as 'online courts' or 'e-courts' to distinguish them from courts that had yet to adopt technologically driven reforms. In some justice systems, these developments were led by courts and Chief Justices (particularly in the USA), and in other places the developments were supported by organizations that were external to the court, ${ }^{3}$ by government or a combination of judicial officers working with government (for example in the UK and in China with the 'smart court' initiatives).

In 2020, as a result of the COVID-19 pandemic, more courts began to change how they operated or enhanced and accelerated technological changes that were already underway. ${ }^{4}$ Some courts were not, however, able to rapidly

1 See examples noted at $<$ https://remotecourts.org/> accessed 24 September 2020.

2 Monika Zalnieriute and Felicity Bell, 'Technology and the Judicial Role' in Gabrielle Appleby and Andrew Lynch (eds), The Judge, the Judiciary and the Court: Individual, Collegial and Institutional Judicial Dynamics in Australia (Cambridge University Press, 2020).

3 John Greacen, Institute for the Advancement of the American Legal System, Eighteen Ways Courts Should Use Technology to Better Serve their Customers (Report, October 18); Erika Rickard, 'Project: Civil Legal System Modernization', PEW (Web Page) $<$ https://www.pewtrusts.org/en/projects/civil-legal-system-modernization> accessed 11 September 2020.

4 See, for example: Courts and Tribunals Judiciary, The Remote Access Family Court (Version 3, 3 April 2020). 
convert court systems to a remote mode of operating and, as a result, delay, postponement and confusion surrounded court activities, with jurisdictional novelty a feature of 2020 responses to a global pandemic (see discussion in Chapter 2). ${ }^{5}$ In some instances, a shift to a remote court operation could not be undertaken because of judicial, court or societal issues that included a lack of access to technology or an inability to use existing technologies. ${ }^{6}$

This book is directed at mapping these changes, considering how judges use existing technologies and how technological change, often accompanied by sophisticated forms of artificial intelligence (AI), may alter and impact on the judicial function into the future. In this regard, distinctions can be drawn about the types of technological reforms that may reshape the judicial role and justice systems, and some reforms may have fewer impacts than others. For example, as discussed below, first and at the most basic level, technology can assist to inform, support and advise people involved in justice activities ('supportive technologies'). Second, technology can replace activities and functions that were previously carried out by humans ('replacement technologies'). Finally, at a third level, technology can provide for very different forms of justice, particularly where processes change significantly ('disruptive technologies'). Many changes in court systems to date have focused on the development of supportive technologies.

At each of these levels, judicial roles may be impacted and the level and type of judicial engagement may differ. This is partly because judges and courts vary extensively, with different functions, systems and processes in place in

5 For example, in Uganda, court responses to the COVID-19 pandemic were equated to the ability to issue judgments and rulings to parties via email: Paul Ampurire, 'Chief Justice Suspends Court Sessions Due to Coronavirus', Soft Power News (Blog Post, 20 March 2020) <https://www.softpower.ug/chief-justice-suspends -court-sessions-due-to-coronavirus/> accessed 11 September 2020. This is in comparison to courts in China, which were conducting entire litigation processes online: Xinhua, 'Across China: Internet Court Handles Cases Despite Coronavirus Epidemic', China.org.cn (Blog Post, 10 March 2020) <http://www.china.org.cn/china/Off the _Wire/2020-03/10/content_75796760.htm> accessed 11 September 2020.

6 For example, an interim report issued by the Equality and Human Rights Commission found that 'video hearings can significantly impede communication and understanding for disabled people': Equality and Human Rights Commission, Inclusive Justice: A System Designed for All (Interim Evidence Report, 22 April 2020) 2.

7 This material is drawn from and discussed in more detail in Tania Sourdin, 'Justice and Technological Innovation' (2015) 25 Journal of Judicial Administration 96, 105. This taxonomy is also discussed in: Tania Sourdin, Bin Li and Tony Burke, 'Just, Quick and Cheap? Civil Dispute Resolution and Technology' (2019) 19 Macquarie Law Journal 17, 19; Tania Sourdin, 'Judge v Robot: Artificial Intelligence and Judicial Decision-Making' (2018) 41(4) University of New South Wales Law Journal 1114, 1118. 
different courts across the globe (see Chapter 2). It is, however, primarily at the second level (replacement technologies) and at the third level (disruptive technologies) where more significant ethical and other issues may surface. At all three levels, there can be questions about innovation readiness and the preparedness of courts, judges, legal practitioners and the justice system more broadly to embrace technological change. ${ }^{8}$ In addition, there are ongoing questions about the appropriateness of changes that may not only transform the work of individual judges but also transform the justice system and the place of judges within society.

\section{JUDGES AND SUPPORTIVE TECHNOLOGICAL CHANGES}

A number of courts and judges have made increasing and extensive use of supportive technologies. These include using websites, basic 'justice apps' ${ }^{\prime}$ and information systems to inform and support court users. ${ }^{10}$ In the past commentators have urged courts to increase innovation by resolving disputes online or over the phone. ${ }^{11}$ However it is only recently that supportive technologies which enable videoconferencing have flourished in courts in the context of a global pandemic. ${ }^{12}$ For example, court hearings and some other work under-

8 See generally: Tania Sourdin, Bin Li and Tony Burke, 'Just, Quick and Cheap? Civil Dispute Resolution and Technology’ (2019) 19 Macquarie Law Journal 17.

9 'Justice apps' are mobile or web-based platforms that purport to assist individuals with legal tasks. There has also been growth in legal 'chatbots' and more recently voice bots. Bots can offer legal advice based on conditional and causal decision logic trees, and in some instances, more sophisticated AI techniques. Apps and bots are discussed in more detail in Tania Sourdin, Jacqueline Meredith and Bin Li, Digital Technology and Justice: Justice Apps (Routledge, 2020).

10 For example, the Supreme Court of New South Wales has available a mobile app which allows users to search court lists and also links users through to interactive maps detailing the court's location: 'Court Lists', Supreme Court of New South Wales (Web Page, 3 April 2020) <http://www.supremecourt.justice.nsw.gov.au/Pages/sco2 _courtlists/sco2_courtlists.aspx $>$ accessed 11 September 2020.

11 David Steven, Maaike de Langen, Sam Muller and Mark Weston, Justice for All and the Public Health Emergency (Justice in a Pandemic - Briefing One, April 2020) 5.

12 See, for example: New South Wales Bar Association, COVID-19: Information for Attending Court (Guide, 6 April 2020); Family Court of Australia and Federal Circuit Court of Australia, Joint Practice Direction (JPD 2 - Special Measures in response to COVID-19, 2020); Judiciary of England and Wales, Civil Justice in England and Wales: Protocol Regarding Remote Hearings (Protocol, 26 March 2020); New York State Unified Court System, 'Virtual Court Operations to Commence in NYC Mid-week' (Press Release, 22 March 2020); 'Consolidated Notice to the Profession, Litigants, Accused Persons, Public and the Media', Superior Court of Justice (Web 
taken by judges can now take place in environments that are entirely remote, ${ }^{13}$ with the use of videoconferencing technology obviating the need for judges, legal practitioners, or parties to be physically present in a courtroom. ${ }^{14}$ Many courts around the globe responded to access to justice in the COVID-19 period by supporting remote hearings. ${ }^{15}$ The UK Family Court and Family Division of the High Court is one example, establishing a 'Remote Access Family Court' enabling disputes to be heard on a virtual access basis. ${ }^{16}$

An analysis of court responses to COVID-19 in 2020 shows that a number of courts used varying processes to shift to online hearing and case management approaches as a result of the COVID-19 pandemic (see later the discussion in Chapter 2 and Table 2.1). Often, the capacity to rapidly change ways of operating has been dependent on the circumstances of litigants (see Chapter 5 in relation to the digital divide) and the extent to which a court has already embraced technological change, ${ }^{17}$ as well as the extent to which there is funding and judicial enthusiasm to enable a court to do so. ${ }^{18}$ Funding levels are

Page, 13 May 2020) <https://www.ontariocourts.ca/scj/notices-and-orders-covid-19/ consolidated-notice/> accessed 11 September 2020.

13 Courtroom technology has been broadly defined in a somewhat dated manner as 'any system or method that uses technology in the form of electrical equipment to provide a clear benefit to the judicial process' - see Jane Donoghue, 'The Rise of Digital Justice: Courtroom Technology, Public Participation and Access to Justice' (2017) 80(6) The Modern Law Review 995, 998, citing Martin Gruen, The World of Courtroom Technology (Center for Legal and Court Technology, 2003).

14 Monika Zalnieriute and Felicity Bell, 'Technology and Judicial Role' in Gabrielle Appleby and Andrew Lynch (eds), The Judge, the Judiciary and the Court: Individual, Collegial and Institutional Judicial Dynamics in Australia (Cambridge University Press, 2020).

15 At times these included changing arrangements for jury trials, see: Corinne Ramey, 'Covid Is No Excuse for Grand Jury Duty When You Can Serve From Your Bedroom', The Wall Street Journal (Online, 20 August 2020) < https://www.wsj.com/ articles/covid-courts-virtual-jury-duty-zoom-wifi-indictments-grand-jury-pandemic -lockdown-11597931499?mod=e2tw> accessed 2 September 2020.

16 Courts and Tribunals Judiciary, The Remote Access Family Court (Version 3, 3 April 2020).

17 Justice Committee, Coronavirus (COVID-19): The Impact on Courts (House of Commons Paper No 519, Session 2019-21) 3.

18 For example, British Columbia's Civil Resolution Tribunal was able to 'remain fully operational' during the COVID-19 pandemic due to it embracing technological change and operating as a wholly online system since 2016: 'The Civil Resolution Tribunal and Strata Disputes', British Columbia $<$ https:/www2.gov.bc.ca/gov/content/ housing-tenancy/strata-housing/resolving-disputes/the-civil-resolution-tribunal> accessed 13 August 2020; Elizabeth Raymer, 'B.C.'s Civil Resolution Tribunal Keeps “Doors Open” During Pandemic', Canadian Lawyer (Blog Post, 27 March 2020) <https://www.canadianlawyermag.com/practice-areas/adr/b.c.s-civil-resolution -tribunal-keeps-doors-open-during-pandemic/328037> accessed 11 September 2020. 
particularly relevant as the underfunding of courts was an early 21 st-century feature of government policy in many countries. ${ }^{19}$ Additionally, in many jurisdictions, a bifurcation was present: civil courts were able to continue to operate while criminal courts could not. For example, it has been noted in England that 'digital technology has enabled certain civil jurisdictions to operate close to normal pre-COVID-19 levels' (emphasis added). ${ }^{20}$

At the same time, evidence from decades of research work suggests that clients (and perhaps to a lesser extent lawyers) are enthusiastic about supportive online approaches to justice, with many perceiving online approaches as enabling access to justice. ${ }^{21}$ For example, in 2020 a review of arrangements in UK courts that were the result of COVID-19 changes found evidence for high levels of 'satisfaction' with remote hearings among many users. ${ }^{22}$ However, despite enthusiasm for online options over nearly two decades, in many jurisdictions, reforms in the court and judicial areas have been sluggish.

In this regard, the many supportive technologies currently used outside court systems which feature supportive apps and bots, have so far had limited court uptake. However, the author notes that there has been some sophisticated development of these technologies in the broader justice sector (see the discussion below relating to replacement technologies).

Often, supportive technologies that rely on and can encourage digitization can have many benefits and pave the way for the development of additional technological developments (see discussion below). In addition, many commentators have argued that the digitization of court processes is the key to ensuring that principles of access to justice are maintained. ${ }^{23}$ However, the

19 See, for example: Patrick Pantano and Anne-Louise Brown, '\$20m Funding Increase, Single National Legal Assistance Mechanism Do Little to Address Huge "Justice Deficit", Law Council of Australia (Blog Post, 2 April 2019) <https:// www.lawcouncil.asn.au/media/media-releases/20m-funding-increase-single-national -legal-assistance-mechanism-do-little-to-address-huge-justice-deficit> accessed 11 September 2020.

20 Justice Committee, Coronavirus (COVID-19): The Impact on Courts (House of Commons Paper No 519, Session 2019-21) 13.

${ }_{21}$ Melissa Conley Tyler, Di Bretherton and Brock Bastian, Research into Online Alternative Dispute Resolution: Needs Assessment (Report, 2003).

22 Justice Committee, Coronavirus (COVID-19): The Impact on Courts (House of Commons Paper No 519, Session 2019-21) 16, citing Natalie Byrom, Sarah Beardon and Abby Kenrick, Civil Justice Council, The Impact of COVID-19 Measures on the Civil Justice System (Report, May 2020). Note these reports are discussed in greater details in later chapters where it is noted that the perceptions of more vulnerable people may not be as positive - see Chapter 6 .

23 See, for example: Sir Andrew McFarlane, President of the Family Division and Head of Family Justice, COVID-19: National Guidance for the Family Court (Guidance, 19 March 2020) [2]. 
extent to which the digitization is supportive can vary. For example, in a 2019 speech titled 'Technology and the Future of the Courts', Chief Justice Allsop of the Federal Court of Australia distinguished between 'internal' and 'external' digitization processes. ${ }^{24}$ The former describes standard developments, such as the e-filing of documents and online databases. The latter is client-facing and encompasses more ambitious external and large-scale digital modernization projects (see the discussion regarding externally facing case management systems in Chapter 4$){ }^{25}$

\section{JUDGES AND REPLACEMENT TECHNOLOGIES}

At the replacement technology level, the development of case management systems, online filing systems and more sophisticated and accessible systems that can include apps, and basic chat or voice bots have been a feature of some more evolved courts. ${ }^{26}$ Susskind has identified such systems as being used to 'improve, refine, streamline, optimize, and turbo-charge our traditional ways of working' ${ }^{27}$ Susskind terms this approach to court technology 'automation', or 'grafting new technology onto old working practices'. ${ }^{28}$ Although this approach may change the way in which courts and judges work, the changes assume that court operations will continue in a manner that resembles those of the past.

In recent years there has also been a significant growth in online dispute resolution (ODR) (see Chapter 4) which can be enabled by supportive and replacement technologies. As outlined by Legg, ODR is a broad term encompassing both alternative dispute resolution (ADR) which is conducted online, and systems of online courts. ${ }^{29}$ More specifically, the author, together with

${ }^{24}$ James Allsop, 'Technology and the Future of the Courts' (Speech, TC Beirne School of Law, University of Queensland, 26 March 2019) 5.

25 James Allsop, 'Technology and the Future of the Courts' (Speech, TC Beirne School of Law, University of Queensland, 26 March 2019) 5.

26 A good example is CaseLines, an online filing and e-bundling platform which is used in UK courts: Courts and Tribunals Judiciary, The Remote Access Family Court (Version 3, 3 April 2020) [5.7]. Also see generally: 'About Us', CaseLines (Web Page) $<$ https://caselines.com/about-us> accessed 13 August 2020.

27 Richard Susskind, Online Courts and the Future of Justice (Oxford University Press, 2019) 34 .

${ }_{28}$ Richard Susskind, Online Courts and the Future of Justice (Oxford University Press, 2019) 34 .

29 Michael Legg, 'The Future of Dispute Resolution: Online ADR and Online Courts' (2016) 27(4) Australasian Dispute Resolution Journal 227, 227. The author notes that the definition of ODR can be somewhat contentious. See Doug Van Epps, 'Assessing the Role - and Purpose - of ODR in Our Courts' (2020) 26(2) Dispute Resolution Magazine 13. For example, some suggest that dispute resolution processes 
Liyanage, has noted that ODR can include facilitative processes such as online mediation, advisory processes such as online case appraisal, and determinative processes such as online arbitration or adjudication. ${ }^{30}$

Developments in ODR also have the capacity to reshape court activities and impact on the judicial role. The impact arises partly because ODR systems can enable greater access to justice by providing additional dispute resolution options and by informing and supporting disputants so that earlier resolution is possible. ${ }^{31}$ Also, as the systems that are developed can be used to gather data they can provide a platform for the development of forms of AI that potentially have a direct impact on judges and may even lead to the replacement of judges ('Judge AI' - see discussion below).

ODR advisory and determinative processes can use a range of simplistic as well as more advanced AI processes. Such systems may go beyond providing information, instead taking a more active role in the finalization of disputes. ${ }^{32}$ Perhaps the most widely used dispute resolution format in the world is established outside the court system through eBay and Paypal's ODR system, which handles approximately 60 million disputes per year. ${ }^{33}$ In the United States, commercial ODR operator Modria (now part of Tyler Technology) ${ }^{34}$ has been estimated to have resolved more than 1 billion disputes in these areas and in respect of more extensive simple claims. ${ }^{35}$ ODR has also been embraced on

that use videoconferencing platforms fall within the definition of ODR. Others may suggest that ODR requires that technology must play a more significant role for it to be defined as ODR: A Schmitz and J Martinez, 'ODR Providers Operating in the U.S.' (Research Paper No 2020-14, University of Missouri School of Law, May 2020).

30 Tania Sourdin and Chinthaka Liyanage, 'The Promise and Reality of Online Dispute Resolution in Australia' in Mohamed S Abdel Wahab, Ethan Katsh and Daniel Rainey (eds), Online Dispute Resolution: Theory and Practice: A Treatise on Technology and Dispute Resolution (Eleven International Publishing, 2012) 483, 484.

31 Erika Rickard, 'Technology Solutions Can Help Modernize U.S. Civil Courts: Resources for Policymakers, Court Officials Who are Considering Adopting Online Dispute Resolution', PEW (Blog Post, 14 April 2020) <https://www.pewtrusts.org/en/ research-and-analysis/articles/2020/04/14/technology-solutions-can-help-modernize -us-civil-courts> accessed 2 September 2020.

32 Ayelet Sela, 'Can Computers Be Fair? How Automated and Human-Powered Online Dispute Resolution Affect Procedural Justice in Mediation and Arbitration' (2018) 33 Ohio State Journal on Dispute Resolution 91, 100.

33 Tania Sourdin, Alternative Dispute Resolution (5th ed, Lawbook Co, 2016) 393.

34 See for example: 'Online Dispute Resolution: Modria in Action' Tyler Technologies (Web Page) <https://www.tylertech.com/resources/videos-and-webinars/ online-dispute-resolution-modria-in-action> accessed 13 August 2020.

35 'Modria: Increase Access to Justice with Online Dispute Resolution', Tyler Technologies (Web Page) <https://www.tylertech.com/products/Modria $>$ accessed 13 August 2020. Notably, a Client Case Study conducted in the Travis County Small Claims Court further revealed that ' $60 \%$ of cases that utilised ODR were resolved 
a much larger scale by the European Union (EU). EU Regulation 524/2013 created an ODR tool to assist consumers and retailers with consumer disputes. Since its initiation in January 2016, there have been more than 8.5 million visitors to the service and 120,000 claims made through the system. ${ }^{36}$ ODR processes can be regarded as disruptive where they include AI processes which may not involve a 'human' practitioner (see discussion below). ${ }^{37}$

A number of international ODR projects act as 'add-on' systems to traditional justice systems and some ODR systems exist within courts. For example, in Utah's Small Claims Court, an ODR system adopted in September 2018 is able to manage an entire dispute online. ${ }^{38}$ The Civil Resolution Tribunal (CRT), established in British Columbia in 2012, ${ }^{39}$ is a wholly-online Tribunal that deals with small claims and condominium disputes, as well as motor vehicle accident and injury claims. ${ }^{40}$ The CRT provides tailored legal information, tools and resources to help parties resolve their dispute. ${ }^{41}$ As of July 2020, the CRT reported 16,194 completed disputes. ${ }^{42}$ Notably, the digital nature of the CRT enabled it to 'remain fully operational' throughout the 2020 global pandemic. ${ }^{43}$

directly by the parties involved without intervention from a mediator or the court': Modria: A Total Tyler Solution, Client Case Study: Travis County Small Claims Court (Report) 2.

36 European Commission, Report from the Commission to the European Parliament, the Council and the European Economic and Social Committee on the application of Directive 2013/11/EU of the European Parliament and of the Council on alternative dispute resolution for consumer disputes and Regulation (EU) No 524/2013 of the European Parliament and of the Council on online dispute resolution for consumer disputes (Report No 425, 25 September 2019) 6, 14.

37 Tania Sourdin and Chinthaka Liyanage, 'The Promise and Reality of Online Dispute Resolution in Australia' in Mohamed S Abdel Wahab, Ethan Katsh and Daniel Rainey (eds), Online Dispute Resolution: Theory and Practice: A Treatise on Technology and Dispute Resolution (Eleven International Publishing, 2012) 483, 484.

38 See Justice Deno Himonas, 'Utah's Online Dispute Resolution Program' (2018) 122(3) Dickinson Law Review 875, 881.

39 Civil Resolution Tribunal Act 2012 (British Columbia) clause 25.

40 See, for example: Peter Kenneth Cashman and Eliza Ginnivan, 'Digital Justice: Online Resolution of Minor Civil Disputes and the Use of Digital Technology in Complex Litigation and Class Actions' (2019) 19 Macquarie Law Journal 39, 44.

${ }_{41}$ Michael Legg, 'The Future of Dispute Resolution: Online ADR and Online Courts' (2016) 27(4) Australasian Dispute Resolution Journal 227, 230.

42 Civil Resolution Tribunal, CRT Statistics Snapshot - July 2020 (Web Page, 13 August 2020) $<$ https://civilresolutionbc.ca/crt-statistics-snapshot-july-2020/> accessed 11 September 2020.

43 The Civil Resolution Tribunal and Strata Disputes', British Columbia (Web Page, 31 May 2017) <https://www2.gov.bc.ca/gov/content/housing-tenancy/strata-housing/ resolving-disputes/the-civil-resolution-tribunal $>$ accessed 13 August 2020; Elizabeth 
There are some technological developments that can initially involve the replacement of humans which can also disrupt justice system operations. For example, in the five years from 2015 to 2020, there has also been a significant growth in 'justice apps' or 'legal apps' - mobile and web-based applications that purport to assist individuals with legal tasks. ${ }^{44}$ More sophisticated 'robolawyer' apps can offer recommendations or solutions based on conditional and causal decision logic trees, and in some cases, more advanced AI techniques. ${ }^{45}$ In addition, both bots and apps are increasingly being used in the justice sector to assist with referring disputes to humans (lawyers, mediators and experts) and to provide advice and support to people who may be engaged in court processes and are increasingly relying on AI to help them do so. ${ }^{46}$

Such replacement technologies can be used in online courts which, as Susskind argues, are clear illustrations of transformation, with such technologies going beyond a simple sustaining or streamlining of current court systems. ${ }^{47}$ Notably, this level of technological change can involve more significant and wide-reaching changes that can reshape the way that courts operate (see Chapter 4).

Raymer, 'B.C.'s Civil Resolution Tribunal Keeps “Doors Open” During Pandemic', Canadian Lawyer (Blog Post, 27 March 2020) <https://www.canadianlawyermag.com/ practice-areas/adr/b.c.s-civil-resolution-tribunal-keeps-doors-open-during-pandemic/ 328037> accessed 13 August 2020.

44 See Tania Sourdin, Jacqueline McKenzie and Bin Li, Digital Technology and Justice: Justice Apps (Routledge, 2020). See also Teresa Scassa, Amy Salyzyn, Jena McGill and Suzanne Bouclin, 'Developing Privacy Best Practices for Direct-to-Public Legal Apps: Observations and Lessons Learned' (2020) 18(1) Canadian Journal of Law and Technology (forthcoming).

45 Judith Bennett, Tim Miller, Julian S Webb, Rachel Bosua, Adam Lodders and Scott Chamberlain, 'Current State of Automated Legal Advice Tools' (Discussion Paper No 1, The University of Melbourne, April 2018) 26. See also Sherley Cruz, 'Coding for Cultural Competency: Expanding Access to Justice with Technology' (2019) 86 Tennessee Law Review 347, 364.

46 Tania Sourdin, Bin Li, Stephanie Simm and Alexander Connolly, 'COVID-19, Technology and Family Dispute Resolution' (2020) 30 Australasian Dispute Resolution Journal (forthcoming).

47 Richard Susskind, Online Courts and the Future of Justice (Oxford University Press, 2019) 35 . 


\section{DISRUPTIVE TECHNOLOGICAL CHANGE AND JUDGES}

It is at the third 'disruptive' level that technology can 'displace and revolutionize conventional working habits and bring radical change' ${ }^{48}$ Often, such changes are linked to the development of AI. AI is used in this book as an umbrella term which encompasses branches of science and technology and often involves the creation of complex algorithms to enable decisions to be made. ${ }^{49}$ Machine learning is currently one emerging dominant mode of AI. ${ }^{50}$ Machine-learning tools offer the potential to make more accurate decisions, based on larger quantities of data than humans are capable of processing. ${ }^{51}$ According to Coglianese and Lehr, this is because machine-learning algorithms differ from traditional statistical techniques in two principal ways. ${ }^{52}$ First, machine-learning algorithms are able to make predictions. ${ }^{53}$ In this sense, machine-learning algorithms allow the actual data to 'dictate how information contained in input variables is put together to forecast the value of an output variable'. ${ }^{54}$ This is in contrast to more traditional methods of AI, which

48 Richard Susskind, Online Courts and the Future of Justice (Oxford University Press, 2019) 34.

49 Tania Sourdin and Richard Cornes, 'Do Judges Need to be Human? The Implications of Technology for Responsive Judging' in Tania Sourdin and Archie Zariski (eds), The Responsive Judge: International Perspectives (Springer, 2018) 87, 89.

50 Harry Surden, The Ethics of Artificial Intelligence in Law: Basic Questions (Draft paper for the Oxford Handbook of Ethics of AI, 2020). See also: Cary Coglianese and David Lehr, 'Regulating by Robot: Administrative Decision Making in the Machine-Learning Era' (2017) 105 The Georgetown Law Journal 1147.

51 Tania Sourdin and Richard Cornes, 'Do Judges Need to be Human? The Implications of Technology for Responsive Judging' in Tania Sourdin and Archie Zariski (eds), The Responsive Judge: International Perspectives (Springer, 2018) 87, 87; Cary Coglianese and David Lehr, 'Regulating by Robot: Administrative Decision Making in the Machine-Learning Era' (2017) 105 The Georgetown Law Journal 1147, 1158 .

52 Cary Coglianese and David Lehr, 'Regulating by Robot: Administrative Decision Making in the Machine-Learning Era' (2017) 105 The Georgetown Law Journal 1147, 1156-1157.

53 Cary Coglianese and David Lehr, 'Regulating by Robot: Administrative Decision Making in the Machine-Learning Era' (2017) 105 The Georgetown Law Journal 1147, 1156.

54 Cary Coglianese and David Lehr, 'Regulating by Robot: Administrative Decision Making in the Machine-Learning Era' (2017) 105 The Georgetown Law Journal 1147, 1156-1157. 
have been more focused on a review of how well the data conform to particular pre-selected choices in terms of outcomes. ${ }^{55}$

The second way in which machine-learning differs from traditional techniques is through an ability to learn. ${ }^{56}$ As data is collected and analysed, the algorithms are continuously updating and modifying their calculations to eventually enable more accurate predictions to be made. ${ }^{57}$ Thus, if performing well, machine-learning algorithms may produce automated results or decisions that more accurately approximate those that would have been made by a similarly situated human. ${ }^{58}$ In the context of the justice sector, machine learning can have a significant impact on litigation outcome prediction, the automated examination of legal documents, and the analysis of factual matters within a legal context. ${ }^{59}$

Processes conducted through AI can use coded logic or algorithms to make a decision, part of a decision, or a recommendation. ${ }^{60}$ As outlined by Parasuraman and Riley, the process of automation is 'characterised by a continuum of levels rather than as an all-or-none concept' ${ }^{61}$ This means decisions can be either wholly or partially automated, with some requiring human involvement at the decision-making stage, and others operating autonomously

55 Cary Coglianese and David Lehr, 'Regulating by Robot: Administrative Decision Making in the Machine-Learning Era' (2017) 105 The Georgetown Law Journal 1147, 1156.

${ }_{56}$ Cary Coglianese and David Lehr, 'Regulating by Robot: Administrative Decision Making in the Machine-Learning Era' (2017) 105 The Georgetown Law Journal 1147, 1157.

57 Cary Coglianese and David Lehr, 'Regulating by Robot: Administrative Decision Making in the Machine-Learning Era' (2017) 105 The Georgetown Law Journal 1147, 1157.

58 Harry Surden, 'Machine Learning and Law' (2014) 89 Washington Law Review $87,90$.

59 Harry Surden, The Ethics of Artificial Intelligence in Law: Basic Questions (Draft paper for the Oxford Handbook of Ethics of AI, 2020); Dean Alderucci and Kevin Ashley, 'Using AI to Analyze Patent Claim Indefiniteness' (2020) 9(1) IP Theory 1. Indeed there are a number of tools that exist in this regard. See, for example: 'CARA A.I.', Casetext (Web Page, 2020) < https://casetext.com/cara-ai/> accessed 7 September 2020; 'Lex Machina', LexMachina: A LexisNexis Company (Web Page) $<$ https://lexmachina.com/legal-analytics/> accessed 7 September 2020; 'Ross Intelligence', ROSS (Web Page) <https://www.rossintelligence.com/> accessed 7 September 2020; 'Ravel Law', RAVEL: A LexisNexis Company (Web Page) <https:// home.ravellaw.com/> accessed 7 September 2020.

${ }^{60}$ Australian Government, Automated Assistance in Administrative Decision-Making: Better Practice Guide (Guide, February 2007) 4.

${ }_{61}$ Raja Parasuraman and Victor Riley, 'Humans and Automation: Use, Misuse, Disuse, Abuse' (1997) 39(2) Human Factors 230, 232. 
without a human decision maker. ${ }^{62}$ They can also be integrated at different stages of a decision-making process and involve differing degrees of human oversight and verification. ${ }^{63}$

As previously mentioned, machine-learning algorithms continuously update their calculations and hence can 'learn' how to make more accurate predictions as more and more data passes through their program. ${ }^{64}$ In this sense, the learned knowledge or experience that would typically inform a person's outcome prediction is now an element which is no longer unique to human decision making. ${ }^{65}$ A good example of this is provided by a 2016 study conducted by Google's DeepMind researchers. ${ }^{66}$ In the study, researchers successfully used supervised and reinforcement learning techniques to train an AI program, AlphaGo, to play the notoriously challenging game of Go ${ }^{67} \mathrm{In}$ doing so, researchers reported that the AlphaGo program 'defeated the human European Go champion by 5 games to $0^{\prime} .^{68}$

There have also been a number of attempts to algorithmically predict court case outcomes. ${ }^{69}$ For example, a machine-learning algorithm developed by

62 Justice Melissa Perry, 'iDecide: Administrative Decision-Making in the Digital World' (2017) 91 Australian Law Journal 29, 29; Cary Coglianese and David Lehr, 'Regulating by Robot: Administrative Decision Making in the Machine-Learning Era' (2017) 105 The Georgetown Law Journal 1147, 1173-1175.

63 Justice Melissa Perry, 'iDecide: Administrative Decision-Making in the Digital World' (2017) 91 Australian Law Journal 29, 29-30; Cary Coglianese and David Lehr, 'Regulating by Robot: Administrative Decision Making in the Machine-Learning Era' (2017) 105 The Georgetown Law Journal 1147, 1173-1175.

${ }^{64}$ Cary Coglianese and David Lehr, 'Regulating by Robot: Administrative Decision Making in the Machine-Learning Era' (2017) 105 The Georgetown Law Journal 1147, 1157.

65 Nicola Lettieri, Antonio Altamura, Rosalba Giugno, Alfonso Guarino, Delfina Malandrino, Alfredo Pulvirenti, Francesco Vicidomini and Rocco Zaccagnino, 'Ex Machina: Analytical Platforms, Law and the Challenges of Computational Legal Science' (2018) 10 Future Internet 37.

66 David Silver, Aja Huang, Chris J Maddison, Arthur Guez, Laurent Sifre, George van den Driessche, Julian Schrittwieser, Ioannis Antonoglou, Veda Panneershelvam, Marc Lanctot, Sander Dieleman, Dominik Grewe, John Nham, Nal Kalchbrenner, Ilya Sutskever, Timothy Lillicrap, Madeleine Leach, Koray Kavukcuoglu, Thore Graepel and Demis Hassabis, 'Mastering the Game of Go with Deep Neural Networks and Tree Search' (2016) 529 Nature 484.

${ }_{67}$ David Silver et al., 'Mastering the Game of Go with Deep Neural Networks and Tree Search' (2016) 529 Nature 484.

68 David Silver et al., 'Mastering the Game of Go with Deep Neural Networks and Tree Search' (2016) 529 Nature 484, 484.

${ }_{69}$ Many of these have been in the private sector. See, for example: Michael Cross, 'Computer Says Win: Funder Ties Up with Case Prediction Startup', The Law Society Gazette (Online, 20 August 2020) <https://www.lawgazette.co.uk/practice/computer -says-win-funder-ties-up-with-case-prediction-startup/5105383.article $>$ accessed 2 
computer scientists at University College London, was able to predict decisions $(\mathrm{n}=584)$ of the European Court of Human Rights with 79 per cent accuracy by applying natural language processing and machine-learning algorithms to text-based material. ${ }^{70}$ However, as noted by Margaret Beazley, former President of the Australian New South Wales Court of Appeal, the European system may lack the oral tradition which forms a key part of judicial determination in some common law systems. ${ }^{71}$ According to Morison and Harkens, such models can potentially be utilized as a method of triaging cases, in order to deal with rising caseloads. Morison and Harken explain that court applications could be algorithmically assessed based on previous jurisprudence in order to determine the likely outcome of the case, before being sorted (that is, accepted or rejected) prior to human examination. ${ }^{72}$

Chinese courts have begun using AI techniques to assist and supervise judges. ${ }^{73}$ Broadly, these techniques may take one of two forms. On the one hand, many local courts in China are developing case pushing systems which

September 2020; Kevin Ashley, 'A Brief History of the Changing Roles of Case Prediction in AI and Law' (2019) 36(1) Law in Context 93. See also for example: 'What We Do', Lex Machina (Web Page) <https://lexmachina.com/about/> accessed 19 August 2020. Notably, Susskind has indicated that legal analytics company Lex Machina may be able to predict the outcome of patent litigation more accurately than human lawyers: Richard Susskind, Online Courts and the Future of Justice (Oxford University Press, 2019) 282-283. See also: Nicola Lettieri, Antonio Altamura, Rosalba Giugno, Alfonso Guarino, Delfina Malandrino, Alfredo Pulvirenti, Franceso Vicidomini and Rocco Zaccagnino, 'Ex Machina: Analytical Platforms, Law and the Challenges of Computational Legal Science' (2018) 10(37) Future Internet 1, 8.

70 Nikolaos Aletras, Dimitrios Tsarapatsanis, Daniel Preotiuc-Pietro and Vasileios Lampos, 'Predicting judicial decisions of the European Court of Human Rights: A natural language processing perspective' (2016) Peer J Computer Science 1, 2. More extensive and recent approaches are detailed at 'Lex Machina', Lex Machina: A LexisNexis Company (Web Page) <https://lexmachina.com/> accessed 2 September 2020.

71 Margaret Beazley, 'Law in the Age of the Algorithm' (Speech, State of the Profession Address, New South Wales Young Lawyers, Sydney, 21 September 2017) [47].

John Morison and Adam Harkens, 'Re-engineering Justice? Robot Judges, Computerised Courts and (Semi) Automated Legal Decision-Making' (2019) 39(4) Legal Studies 618, 632.

73 Meng Yu and Guondong Du, 'Why Are Chinese Courts Turning to AI?', The Diplomat (Blog Post, 19 January 2019) <https://thediplomat.com/2019/01/why-are -chinese-courts-turning-to-ai/> accessed 13 August 2020. See also: Li Zhonghao and Jiang Hao, 'Anhui R\&D Case Guide Project and Trial', People's Court Daily (News Article, 21 June 2016) <http://rmfyb.chinacourt.org/paper/html/2016-06/21/content _113216.htm> accessed 13 August 2020. 
'push' judgments of similar cases to judges for their reference. ${ }^{74}$ The goal of AI case pushing systems is to ensure that judgment criteria is consistent between analogous cases. ${ }^{75}$ On the other hand, other courts in China are developing 'abnormal judgment' warning systems. ${ }^{76}$ These systems take a risk management approach to supervision and issue alerts to a judge's superior if a decision made 'significantly differs from judgments of similar cases'. ${ }^{77}$ One example of this approach is provided by the Taizhou Intermediate People's Court of Zhejiang Province, which has developed a risk management system aimed at enhancing judicial integrity. ${ }^{78}$ The system works by setting 60 'risk indicators' across seven categories which work to evaluate judicial risks arising from trial, enforcement and administrative activities using colour-coded labels. ${ }^{79}$ As of April 2019, a total of 248 risks had been detected and alerts sent by the system. ${ }^{80}$

Although the application of AI to legal problems has been investigated since the 1970s, rapid developments in recent years have generated new opportu-

74 Meng Yu and Guondong Du, 'Why Are Chinese Courts Turning to AI?', The Diplomat (Blog Post, 19 January 2019) <https://thediplomat.com/2019/01/why-are -chinese-courts-turning-to-ai/> accessed 13 August 2020. See also: Li Zhonghao and Jiang Hao, 'Anhui R\&D Case Guide Project and Trial', People's Court Daily (News Article, 21 June 2016) <http://rmfyb.chinacourt.org/paper/html/2016-06/21/content _113216.htm $>$ accessed 13 August 2020.

75 Meng Yu and Guondong Du, 'Why Are Chinese Courts Turning to AI?', The Diplomat (Blog Post, 19 January 2019) <https://thediplomat.com/2019/01/why-are -chinese-courts-turning-to-ai/> accessed 13 August 2020. See also: Li Zhonghao and Jiang Hao, 'Anhui R\&D Case Guide Project and Trial', People's Court Daily (News Article, 21 June 2016) <http://rmfyb.chinacourt.org/paper/html/2016-06/21/content 113216.htm $>$ accessed 13 August 2020.

${ }^{76}$ Meng Yu and Guondong Du, 'Why Are Chinese Courts Turning to AI?', The Diplomat (Blog Post, 19 January 2019) <https://thediplomat.com/2019/01/why-are -chinese-courts-turning-to-ai/> accessed 13 August 2020. See also: Li Zhonghao and Jiang Hao, 'Anhui R\&D Case Guide Project and Trial ', People's Court Daily (News Article, 21 June 2016) <http://rmfyb.chinacourt.org/paper/html/2016-06/21/content _113216.htm $>$ accessed 13 August 2020.

${ }_{77}$ Meng Yu and Guondong Du, 'Why Are Chinese Courts Turning to AI?', The Diplomat (Blog Post, 19 January 2019) <https://thediplomat.com/2019/01/why-are -chinese-courts-turning-to-ai/> accessed 13 August 2020. See also: Li Zhonghao and Jiang Hao, 'Anhui R\&D Case Guide Project and Trial', People's Court Daily (News Article, 21 June 2016) <http://rmfyb.chinacourt.org/paper/html/2016-06/21/content _113216.htm $>$ accessed 13 August 2020.

78 Supreme People's Court of China, Chinese Courts and Internet Judiciary (White Paper, 4 December 2019) 82.

79 Supreme People's Court of China, Chinese Courts and Internet Judiciary (White Paper, 4 December 2019) 82.

80 Supreme People's Court of China, Chinese Courts and Internet Judiciary (White Paper, 4 December 2019) 82. 
nities. ${ }^{81}$ As noted by Donoghue, the courts and legal profession have been amongst the most conservative professional domains when it comes to technology adoption. However, in recent years, this has changed dramatically, ${ }^{82}$ and while AI processes have emerged over the past 50 years, it is largely only in the last decade that they have been directed at processes within the justice sector. ${ }^{83}$ Outside the justice sector, developments in this area have been significant, and in 2015 the McKinsey Global Institute concluded that, compared to the Industrial Revolution, the AI and big data revolution is 'happening ten times faster and at 300 times the scale, or roughly 3,000 times the impact'. ${ }^{84} \mathrm{~A}$ 2016 survey of machine-learning researchers $(n=352)$ found that 45 per cent of researchers viewed high-level machine intelligence as having a 'good' or 'extremely good' outcome on humanity over the long-run. By contrast, only 10 per cent thought it would have a 'bad outcome', and 5 per cent an 'extremely bad' outcome. ${ }^{85}$

Nevertheless, some scepticism remains about the potential for AI to reshape the justice system in terms of the impact on individual cases. As noted by Morison and Harkens, in most cases, the technology acts primarily 'as a tool to assist in dispute resolution rather than an autonomous system which can actually process, adjudicate or settle disputes independently' ${ }^{86}$ Paliwala similarly notes that changes have resulted primarily from ordinary information technology methods such as data processing, and results have not been as successful when information technology has been applied to deeper legal processes. ${ }^{87}$ According to Sunstein, this is because AI techniques are currently incapable

81 Felicity Bell, 'Family Law, Access to Justice, and Automation' (2019) 19 Macquarie Law Journal 103, 103.

82 Jane Donoghue, 'The Rise of Digital Justice: Courtroom Technology, Public Participation and Access to Justice' (2017) 80(6) The Modern Law Review 995, 997.

83 Tania Sourdin, 'Judge v Robot? Artificial Intelligence and Judicial Decision-Making’ (2018) 41(4) UNSW Law Journal 1114, 1119.

84 Richard Dobbs, James Manyika and Jonathan Woetzel, 'The Four Global Forces Breaking All the Trends', McKinsey Global Institute (Web Page, 1 April 2015) $<$ https://www.mckinsey.com/business-functions/strategy-and-corporate-finance/our -insights/the-four-global-forces-breaking-all-the-trends> accessed 13 August 2020.

${ }^{85}$ Katja Grace, John Salvatier, Allan Dafoe, Baobao Zhang and Owain Evans, 'When Will AI Exceed Human Performance? Evidence from AI Experts' (2018) 62 Journal of Artificial Intelligence Research 729, 733.

${ }^{86}$ John Morison and Adam Harkens, 'Re-engineering Justice? Robot Judges, Computerised Courts and (Semi) Automated Legal Decision-Making' (2019) 39 Legal Studies 618, 622 (emphasis in original).

87 Abdul Paliwala, 'Rediscovering Artificial Intelligence and Law: An Inadequate Jurisprudence?' (2016) 30(3) International Review of Law, Computers \& Technology $107,108$. 
of making the value judgments required by case-based reasoning. ${ }^{88}$ There are also other issues, such as undesirable broader impacts that might include stifling the development of the law (see Chapter 8) or 'dehumanizing' the court experience (see Chapter 9), as well as broader potential negative impacts on governments and societies (see Chapter 7) that may partly arise as a result of the restructuring of governance arrangements in the justice system and courts that may be coupled with a loss of status and respect for judges.

\section{INTRODUCTION TO JUDGE AI}

Judge AI refers to developments in the various branches of AI specifically concerned with contributing to judicial tasks, and can incorporate a range of disruptive technologies. It includes a range of possibilities, from the increasing use of technology in judicial processes prior to trial, to playing a role in decision-making processes ('supportive Judge AI') ${ }^{89}$ or replacing a judge altogether ('Judge AI'). As noted by the author and Cornes, even before a case comes before a judge, AI may have an impact on the judicial task by virtue of its impact on the legal profession and how cases are prepared and presented to the court. ${ }^{90}$ The author has noted that this may include predictive coding developments which can influence which cases get before a judge. Once cases are before courts, supportive Judge AI can also play a role in aspects of judicial decision making. ${ }^{91}$

One simple - and arguably often overlooked - way in which supportive AI can contribute to judicial tasks is by offering administrative assistance. For example, a paper issued by the Supreme People's Court of China explains that Chinese courts have 'been developing various smart assistant platforms

88 Cass Sunstein, 'Of Artificial Intelligence and Legal Reasoning' (Working Paper No. 18, Public Law \& Legal Theory, 2001).

89 Tania Sourdin and Richard Cornes, 'Do Judges Need to be Human? The Implications of Technology for Responsive Judging' in Tania Sourdin and Archie Zariski (eds), The Responsive Judge: International Perspectives (Springer, 2018) 87, 89.

90 For example, lawyers may work with clients and AI to determine whether to progress a matter and how to do so: Lyle Moran, 'Law Firm Teams Up with Canadian Legal Tech Company on AI-powered Case Prediction Tool', ABA Journal (Online, 25 August 2020) <https://www.abajournal.com/web/article/law-firm-teams -up-with-canadian-legal-tech-company-on-ai-powered-case-prediction-tool $>$ accessed 2 September 2020.

${ }_{91}$ Tania Sourdin and Richard Cornes, 'Do Judges Need to be Human? The Implications of Technology for Responsive Judging' in Tania Sourdin and Archie Zariski (eds), The Responsive Judge: International Perspectives (Springer, 2018) 87, 89. 
for administrative works' ${ }^{92}$ Another example is the integrated smart court system used by the Suzhou Intermediate People's Court of Jiangsu Province. ${ }^{93}$ This system allows for an entirely paper-free litigation process by digitizing case files and employing voice-to-text transcription technology for court hearings, voice-command navigation of e-evidence and 'one-click generation' of judgments for simple cases. ${ }^{94}$ This system has proven to be extremely helpful in improving the efficiency of the judicial role, with judges' administrative workload reportedly decreasing by approximately 40 per cent. ${ }^{95}$

However, there are additional ways in which AI can impact the judicial function that are explored throughout this book. In regard to the potential for AI to replace human judges, machine-learning researchers believe there is a 50 per cent chance of AI outperforming humans in all tasks in 45 years, and of automating all human jobs in 120 years. ${ }^{96}$ More specifically, a 2013 study which ranked 702 occupations from least likely to most likely to be replaced by technology predicted that there was a 40 per cent chance of 'Judges, Magistrate Judges, and Magistrates', and a 64 per cent chance of 'Administrative Law Judges, Adjudicators, and Hearing Officers', being replaced by robots. By contrast, in that study, the chance of lawyers being replaced by robots was only 3.5 per cent. ${ }^{97}$

Judge AI can impact on both the procedural and substantive ${ }^{98}$ aspects of judicial decision making. As noted by Zalnieriute and Bell, the automation of procedural steps is quite different to automating a substantive decision, thus demanding 'a nuanced approach' to the use of technology in judicial decision

92 Supreme People's Court of China, Chinese Courts and Internet Judiciary (White Paper, 4 December 2019) 80.

93 Supreme People's Court of China, Chinese Courts and Internet Judiciary (White Paper, 4 December 2019) 81.

94 Supreme People's Court of China, Chinese Courts and Internet Judiciary (White Paper, 4 December 2019) 81.

95 Supreme People's Court of China, Chinese Courts and Internet Judiciary (White Paper, 4 December 2019) 81.

96 Katja Grace, John Salvatier, Allan Dafoe, Baobao Zhang and Owain Evans, 'When Will AI Exceed Human Performance? Evidence from AI Experts' (2018) 62 Journal of Artificial Intelligence Research 729, 729.

${ }_{97}$ Carl Benedikt Frey and Michael A Osborne, 'The Future of Employment: How Susceptible Are Jobs to Computerisation?' (Workshop Paper, Machines and Employment Workshop, 17 September 2013) <http://www.oxfordmartin.ox.ac.uk/ downloads/academic/The_Future_of_Employment.pdf $>$.

98 See for example the discussion in Shang Li, Hongli Zhang, Lin Ye, Xiading Guo and Binxing Fang, 'MANN: A Multichannel Attentive Neural Network for Legal Judgment Prediction' (2019) 7(1) IEEEAccess 151144. 
making. ${ }^{99}$ Tan explains that the degree of automation employed may vary from 'decision-support' to 'human-in-the-loop' processes, and even to the total removal of humans from the decision-making process (see also discussion of 'human-on-the-loop' processes in Chapter 9). ${ }^{100}$

Zalnieriute and Bell distinguish between two waves of AI which can be applied to judicial decision making. The 'first wave' of AI is a process that follows a series of pre-programmed rules to mirror the response of a human expert. EXPERTIUS - a decision-support system used in Mexico to advise judges and clerks as to whether a plaintiff is eligible for a pension - is one example of a 'first wave' AI process. The 'second wave' of AI includes techniques such as supervised machine learning and deep learning. These techniques, as previously noted, enable systems to 'learn' from data in order to draw inferences about new situations. ${ }^{101}$

Judge AI inevitably raises questions relating to ethics and the core values that are relevant in terms of the meaning of justice. Formulating broad ethical frameworks and also articulating the objectives of the justice system can assist in evaluating and determining to what extent technological developments could or should be pursued (see Chapter 9). In this regard, there is some work which can be useful that has been developed at a more micro level (such as that which considers justice apps) ${ }^{102}$ as well as at a more macro level with the emergence of ethical frameworks relating to judicial use of AI. ${ }^{103}$ These matters are more fully explored in Chapters 9 and 10 of this book, and the issues relating to judges in specific contexts are explored more closely in the following chapters.

99 Monika Zalnieriute and Felicity Bell, 'Technology and Judicial Role' in Gabrielle Appleby and Andrew Lynch (eds), The Judge, the Judiciary and the Court: Individual, Collegial and Institutional Judicial Dynamics in Australia (Cambridge University Press, 2020).

100 Vivi Tan, 'Online Dispute Resolution for Small Civil Claims in Victoria: A New Paradigm in Civil Justice' (2019) 24(1) Deakin Law Review 101.

101 See Monika Zalnieriute and Felicity Bell, 'Technology and Judicial Role' in Gabrielle Appleby and Andrew Lynch (eds), The Judge, the Judiciary and the Court: Individual, Collegial and Institutional Judicial Dynamics in Australia (Cambridge University Press, 2020). See also the discussion relating to algorithmic bias in Chapter $3-C O M P A S$, a risk-assessment tool in the United States is provided as an example of a tool that might draw on historical data and use machine learning to infer which convicted defendants pose the highest risk of re-offending.

102 See Tania Sourdin, Jacqueline McKenzie and Bin Li, Digital Technology and Justice: Justice Apps (Routledge, 2020).

103 European ethical Charter on the use of Artificial Intelligence in judicial systems and their environment (entered into force on 3-4 December 2018). 


\section{TECHNOLOGICAL EVOLUTION}

As noted previously, not all courts - nor, for that matter, all judges - are at the same stage of technological development or understanding. However, it is worthwhile to consider the current stages of technological development in the context of overarching trends that impact on many societies around the world. In this regard, Susskind has suggested that advances in technology can be understood under four headings. First, technology is advancing at an 'exponential rate'. ${ }^{104}$ This advance has fuelled a second trend: our systems are becoming 'increasingly capable'. ${ }^{105}$ The third major trend has seen our systems become 'increasingly pervasive'. ${ }^{106}$ Finally, humans are becoming 'increasingly connected'. ${ }^{107}$

The three main and interlinked ways in which technology is reshaping justice systems in terms of supportive, replacement and disruptive technologies discussed previously can also be understood in the context of these overarching trends. ${ }^{108}$ In addition, these three levels, align with the three levels of innovation described by Katsh and Rabinovich-Einy. Katsh and Rabinovich-Einy identify three major phases or 'levels of evolution' in the development of ODR: (i) where information communication technology elements enable the dispute to be compiled and addressed by the parties online; (ii) where straightforward algorithms apply various rules in relation to multiple factors; and (iii) where 'data is collected in bulk quantities and examined and re-used by algorithms so as to analyse patterns and produce predictions or decisions regarding the outcome of a particular case'. ${ }^{109}$

Technological change will therefore often build on the technological change that has preceded it. For example, developments that include the digitization of court records will support the development of AI systems. Developments in data analysis which follow digitization will enable courts to understand far more about who uses the court, how and why, which in turn may lead to revised

104 Richard Susskind, Online Courts and the Future of Justice (Oxford University Press, 2019) 36.

105 Richard Susskind, Online Courts and the Future of Justice (Oxford University Press, 2019) 37.

106 Richard Susskind, Online Courts and the Future of Justice (Oxford University Press, 2019) 39.

107 Richard Susskind, Online Courts and the Future of Justice (Oxford University Press, 2019) 39.

108 This material is drawn from and discussed in more detail in Tania Sourdin, 'Justice and Technological Innovation' (2015) 25 Journal of Judicial Administration $96,105$.

109 Ethan Katsh and Orna Rabinovich-Einy, Digital Justice: Technology and the Internet of Disputes (Oxford University Press, 2017) 33-34. 
case management approaches that are AI dependent. Judges may make their written reasons for a decision more 'machine readable', and such a change will also facilitate the later development of Judge AI. ${ }^{110}$ While many judges may be unconcerned about the first stages in the technological evolutionary cycle they may be more concerned about what might follow initial developments, and, as noted below, some judges have been more critical than others about the potential longer-term impacts.

\section{JUDICIAL COMMENTARY ABOUT TECHNOLOGICAL CHANGE}

To date, a large number of judges have written about and/or presented on the topic of technological change and the justice system, with many recognizing the potential disruptive capacity as well as concerns relating to the ability of courts, judges and others to adjust to changes. ${ }^{111}$ Sundaresh Menon, Chief Justice of Singapore, for example, has noted that 'technology will be the single most potent force to reshape our profession in the years to come'. ${ }^{112}$ In a 2017 interview, John G Roberts Jr, Chief Justice of the United States, was asked '[c] an you foresee a day when smart machines, driven with artificial intelligences, will assist with courtroom fact-finding or, more controversially even, judicial decision making?' The Chief Justice responded: '[i]t's a day that's here, and it's putting a significant strain on how the judiciary goes about doing things'. ${ }^{113}$

However, while many judicial commentators may have some enthusiasm for supportive technologies that enable online hearings and replacement technologies that enable online filing they have not necessarily considered more disruptive technology use that could, for example, encourage Judge AI. For example, in response to the COVID-19 pandemic a number of judges have expressed positive views relating to the use of supportive technology and indicated that some arrangements that have been introduced are likely to remain.

110 Jameson Dempsey and Gabriel Teninbaum, 'May it Please the Bot?', Paper, MIT 15 August 2020, <https://law.mit.edu/pub/mayitpleasethebot/release/1> accessed 20 September 2020.

111 See, for example: James Allsop, 'Technology and the Future of the Courts' (Speech, TC Beirne School of Law, University of Queensland, 26 March 2019).

112 Chief Justice Sundaresh Menon, 'Deep Thinking: The Future of the Legal Profession in an Age of Technology' (Speech, 29th Inter-Pacific Bar Association Annual Meeting and Conference, Raffles City Convention Centre, Singapore, 25 April 2019) [1].

113 Rensselaer Polytechnic Institute, 'A Conversation with Chief Justice John G. Roberts, Jr.' (YouTube, 11 April 2017) <https://www.youtube.com/watch?v= TuZEKIRgDEg $>$ accessed 13 August 2020. 
For example, Chief Justice McCormack of the Michigan Supreme Court, United States, has indicated that 'many pandemic-related "temporary" adjustments are likely to be permanent improvements: "I don't think that things will ever return to the way they were, and I think that is a good thing"'. ${ }^{114}$ At the same time, in reflecting on the changes, Her Honour noted that:

'Most [courts] are learning months' worth of lessons in days. They are learning skills because they had to. Once you have to ... you keep the parts that are helpful. This was not the disruption we wanted, but it was the disruption we needed'. ${ }^{115}$

The limited judicial commentary about the third level of disruptive change is, however, fairly divided in terms of whether or not more extensive technological changes are beneficial or not. To some extent, this is because judicial commentators remain focused on lower levels of technological change, with many not necessarily understanding the potential implication of third-level change or, in any event, perceiving such changes as having impacts on the courts rather than the judges themselves (or perhaps on the next generation of judges after they retire). ${ }^{116}$ In addition, few judges necessarily understand how even basic AI may work. This is perhaps not surprising as judicial and, to some extent, legal education has often tended to focus more on content and less on process. Indeed, there are few courses that have introduced judges to coding or the concepts that could be relevant to the use of more evolved AI (see the discussion in Chapters 5 and 7). ${ }^{117}$

\section{Opportunities}

Marilyn Warren, former Chief Justice of the Supreme Court of Victoria in Australia, has outlined a number of 'good reasons' to urge technological change in the justice system. These include: cost savings; efficiency/time savings; openness with technology providing 'an opportunity for the world to

114 PL Embley, Judicial Perspectives on ODR and Other Virtual Court Processes (Bulletin, Joint Technology Committee, 18 May 2020) 2.

115 PL Embley, Judicial Perspectives on ODR and Other Virtual Court Processes (Bulletin, Joint Technology Committee, 18 May 2020) 2.

116 James Allsop, 'Technology and the Future of the Courts' (Speech, TC Beirne School of Law, University of Queensland, 26 March 2019) 6.

117 See, for example: 'Teaching Algorithms to Lawyers - a Webinar by Dr Khaled Dika', University of Newcastle (Web Page, 8 April 2020) $<$ https://www.newcastle.edu .au/newsroom/faculty-of-business-and-law/teaching-algorithms-to-lawyers-a-webinar -by-dr-khaled-dika> accessed 13 August 2020. 
come into the courtroom'; and a potentially higher quality of justice. ${ }^{118}$ Justice Perry of the Federal Court of Australia has identified that automated processes offer the 'great benefit' of being able to 'process large amounts of data more quickly, more reliably and less expensively than their human counterparts'. ${ }^{119}$ Former Judge of the Supreme Court of New South Wales in Australia, Robert McDougall, has identified a further benefit: how courtroom technology can provide advocates with an invaluable tool to 'persuasively and succinctly' present their case. ${ }^{120}$ Further again, Chief Justice Helen Murrell of the Supreme Court of the Australian Capital Territory, Australia, has acknowledged the potential benefit technology provides to 'enhance the rule of law'. ${ }^{121}$

One of the key reasons judicial attention to technological innovation in law is seen as desirable by the judiciary is because of its potential to ensure the judicial system is not out of touch with the society it is supposed to serve. In this sense, Marilyn Warren, a former Chief Justice of the Supreme Court of Victoria, Australia, warns that there is a risk that judges will lose relevance in society if they do not adapt to technological change. ${ }^{122}$ In the United States, Justice Deno Himonas of the Utah Supreme Court has also observed the potential for Utah's ODR system in its Small Claims Court to 'keep the courts relevant'. ${ }^{123}$ Similarly, Chief Justice of the Federal Court of Australia, James Allsop, has noted that 'AI has shown its value' in making the courts more 'accessible and in line with society's daily digital usage'. ${ }^{124}$

In light of the above benefits, some judges have encouraged the legal profession to accept technological change. Former Chief Justice of the Supreme Court of Canada, Beverley McLachlin, has urged practitioners to accept the reality that some tasks traditionally performed by lawyers can be more efficiently executed through technological means. According to McLachlin,

118 Justice Marilyn Warren, 'Embracing Technology: The Way Forward for the Courts' (2015) 24 Journal of Judicial Administration 227, 235.

119 Justice Melissa Perry, 'iDecide: Administrative Decision-Making in the Digital World' (2017) 91 Australian Law Journal 29, 30.

120 Justice Robert McDougall, 'The Uses and Abuses of Technology in the Courtroom' (Speech, Society of Construction Law, Australia Conference, 2 August 2013) [10].

121 Chief Justice Helen Murrell, 'Turn and Face the Change - New Technology and the Internationalised Judiciary' (Speech, Supreme Court of the Australian Capital Territory, 1 February 2016) 2.

122 Justice Marilyn Warren AC, 'Embracing Technology: The Way Forward for the Courts' (2015) 24 Journal of Judicial Administration 227, 235.

${ }^{123}$ Justice Deno Himonas, 'Utah's Online Dispute Resolution Program' (2018) 122(3) Dickinson Law Review 875, 880-881.

${ }^{124}$ James Allsop, 'Technology and the Future of the Courts' (Speech, TC Beirne School of Law, University of Queensland, 26 March 2019) 7. 
'change should not be seen as an evil, but rather as the source of new opportunities'. ${ }^{125}$ In this regard, Chief Justice Allsop of the Federal Court of Australia, has also identified the need for behavioural change across the profession, stating that 'judges, barristers, lawyers, and also clients and litigants need to be willing to embrace technology in the courts'. ${ }^{126}$

However, as noted above, there are concerns about a third level of change that could displace judges or more directly impact on the judicial role. At this level, Geoffrey Vos, Chancellor of the High Court of England and Wales, has taken a more cautious stance, arguing 'there is no reason whatever why decision-making should be undertaken by machines'. ${ }^{127}$ Rather, Vos claims decision making will simply be assisted and informed by machine processed data. $^{128}$

\section{Challenges}

Current and former judges have also commented on the limitations and challenges associated with the technological development of legal processes. For example, Margaret Beazley, former President of the New South Wales Court of Appeal in Australia, has observed that the 'cost and efficiency of a system that is essentially technologically based cannot be considered without reference to the cost of malfunctions, which includes the cost of down time, the cost of maintenance and repair, and the cost of ever increasing cyber security issues'. ${ }^{129}$ Speaking specifically on the use of technology in judicial decision making, Beazley has also argued that 'the more fact based, complex, and evaluative the legal problem, the less likely online dispute resolution will be an appropriate forum'. ${ }^{130}$

125 Chief Justice Beverley McLachlin, 'The Legal Profession in the 21st Century' (Speech, Canadian Bar Association Plenary, Calgary, 14 August 2015).

126 James Allsop, 'Technology and the Future of the Courts' (Speech, TC Beirne School of Law, University of Queensland, 26 March 2019) 10.

127 Sir Geoffrey Vos, 'The Tech Revolution: A Threat to the Core Values of Civil Society and the Legal Profession - Part 1: Opportunities Provided by Technology and their Correlation with Law, Values and Professional Ethics' (Speech, IBA Annual Conference, Rome, 11 October 2018) [15].

128 Sir Geoffrey Vos, 'The Tech Revolution: A Threat to the Core Values of Civil Society and the Legal Profession - Part 1: Opportunities Provided by Technology and their Correlation with law, Values and Professional Ethics' (Speech, IBA Annual Conference, Rome, 11 October 2018) [15].

129 Margaret Beazley, 'Law in the Age of the Algorithm' (Speech, State of the Profession Address, New South Wales Young Lawyers, Sydney, 21 September 2017) [7].

130 Margaret Beazley, 'Law in the Age of the Algorithm' (Speech, State of the Profession Address, New South Wales Young Lawyers, Sydney, 21 September 2017) [26]. 
Similarly, according to Marilyn Warren (former Chief Justice of the Supreme Court of Victoria in Australia), the courts' democratic duty to balance efficiency, save costs, and provide open and impartial justice, means that not all technologies are appropriate for the courtroom. ${ }^{131}$ This is especially so when one considers the strong customs that underpin legal practices. In this sense, Margaret Beazley, former President of the New South Wales Court of Appeal in Australia, has argued that we must ensure 'that technological change supports the administration of justice and the rule of law and does not supplant it with concepts that are alien to our rich legal tradition'. ${ }^{132}$ In a similar vein, Beverley McLachlin from Canada has argued that:

The integrity of legal processes and the interests of the client must never be sacrificed to efficiency - maintenance of these is the essence of what it is to be a lawyer in service of the public. Flexibility and innovation, yes. Abandonment of core professional values, never. Therein lies the challenge and the opportunity of the future. ${ }^{133}$

A number of judges have also emphasized the 'human element' in judging and noted the limitations of technology in this regard (see also the discussion in Chapters 8 and 9) ${ }^{134}$ Justice See Kee Oon of the Supreme Court of Singapore has argued that 'while technology can lead to greater efficiency and enhance the delivery of justice, the human touch remains essential. In the delivery of justice, human experience, empathy and common sense reasoning play a criti-

131 Justice Marilyn Warren, 'Embracing Technology: The Way Forward for the Courts' (2015) 24 Journal of Judicial Administration 227, 229.

132 Margaret Beazley, 'Law in the Age of the Algorithm' (Speech, State of the Profession Address, New South Wales Young Lawyers, Sydney, 21 September 2017) [6].

133 Chief Justice Beverley McLachlin, 'The Legal Profession in the 21st Century' (Speech, Canadian Bar Association Plenary, Calgary, 14 August 2015).

134 See, for example: Justice GC Martin, 'How Far Has Technology Invaded the Criminal Justice System?' (Speech, Australia and New Zealand Education Law Association, Legal Studies Teachers' Conference, Brisbane, 11 May 2018) [21]; Justice John Middleton, 'The Life of the Trial Judge - What Has or Is Changing?' (Speech, Samuel Griffith Society, 11 August 2019); Chief Justice Tom Bathurst, 'iAdvocate v Rumpole: Who Will Survive? An Analysis of Advocates' Ongoing Relevance in the Age of Technology' (Speech, Australian Bar Association Conference, Boston, 9 July 2015) [7]; Michael Kirby, 'The Commonwealth Lawyer: Law in an Age of Fantastic Technological Change' (Speech, Eighth Greek/Australian International Legal and Medical Conference, 4 June 2001); Michael Kirby, 'The Future of Courts: Do They Have One?' (1999) 8 Journal of Judicial Administration 185; Justice Melissa Perry, 'iDecide: Administrative Decision-Making in the Digital World' (2017) 91 Australian Law Journal 29, 32; James Allsop, 'Technology and the Future of the Courts' (Speech, TC Beirne School of Law, University of Queensland, 26 March 2019) 2. 
cal role'. ${ }^{135}$ Former Justice of the High Court of Australia, Michael Kirby, has made similar remarks regarding the use of technology, stating that machines 'will reduce the risks of human error. But there will remain the need for human support'. ${ }^{136}$ On this topic, Margaret Beazley of Australia has observed (see also Chapter 6 concerning justice objectives):

One matter that cannot be overlooked in the proper functioning of the legal system is the human factor. Legal issues arise out of human conduct and court decisions have an impact on the individuals who participate in them. Individuals need to feel that they are treated 'fairly' in their interaction with the legal system. Fairness in this context is not only in the outcome of their case or resolution of their issue. It is the human need to be listened to. ${ }^{137}$

In addition to concerns about the impersonal and unempathetic nature of machines, ${ }^{138}$ judges have also discussed a number of other issues associated with the use of technology in the law. These include: issues with coding law; ;39 the potential for bias to creep into AI systems; ${ }^{140}$ the need for discretion in

135 Justice See Kee Oon, 'State Courts: 2020 and Beyond' (Speech, State Courts Workplan 2019, 8 March 2019) [11].

136 Michael Kirby, 'The Commonwealth Lawyer: Law in an Age of Fantastic Technological Change' (Speech, Eighth Greek/Australian International Legal and Medical Conference, 4 June 2001).

137 Margaret Beazley, 'Law in the Age of the Algorithm' (Speech, State of the Profession Address, New South Wales Young Lawyers, Sydney, 21 September 2017) [64].

138 For a discussion of this issue in the administrative law context, see: Cary Coglianese and David Lehr, 'Regulating by Robot: Administrative Decision Making in the Machine-Learning Era' (2017) 105 The Georgetown Law Journal 1147, 1219.

139 Lord Sales, 'Algorithms, Artificial Intelligence and the Law' (Speech, Sir Henry Brooke Lecture for BAILII, Freshfields Bruckhaus Deringer, London, 12 November 2019); Justice Melissa Perry, 'iDecide: Administrative Decision-Making in the Digital World' (2017) 91 Australian Law Journal 29, 32.

140 Lord Hodge, 'Law and Technological Change' (Speech, British Irish Commercial Bar Association, Edinburgh, 4 April 2019) [12]; Justice GC Martin, 'How Far Has Technology Invaded the Criminal Justice System?' (Speech, Australia and New Zealand Education Law Association, Legal Studies Teachers' Conference, Brisbane, 11 May 2018). 
decision making; ${ }^{141}$ the perils of online courts; ${ }^{142}$ and the impact of technology on administrative decision making (see discussion in Chapter 8). ${ }^{143}$

Notably, Susskind has outlined three key reasons why judges (and, indeed, lawyers) may be reluctant to embrace new technologies. The first pertains to 'status quo bias', which Susskind explains is a tendency to resist change. ${ }^{144}$ The second reason is termed 'irrational rejectionism', which is defined as the dismissal of a system with which the critic has no direct personal experience. ${ }^{145}$ The final reason is the inability to anticipate that tomorrow's systems will be vastly more capable than those of today. This is termed 'technological myopia'. ${ }^{146}$

Thus, according to Susskind, judges strongly resist any technological shifts that directly impact on and are transformative to the judicial role. ${ }^{147}$ However, as noted previously, to date most judicial commentators have primarily focused on the impact of technological change on the profession or the law, rather than the judiciary itself. For example, Sundaresh Menon, Chief Justice of Singapore, has outlined four key areas in which technology impacts on the law:

(i) First, Menon notes the impact upon legal education and training, with questions arising as to how best to train the next generation of legal practitioners;

(ii) Second, Menon argues technology has a significant impact on the organization of the legal profession. At the law-firm level, the traditional

141 Justice G C Martin, 'How Far Has Technology Invaded the Criminal Justice System?' (Speech, Australia and New Zealand Education Law Association, Legal Studies Teachers' Conference, Brisbane, 11 May 2018) [20].

142 Justice Anna Katzmann, 'The Future Role of the Judge - Umpire, Manager, Mediator or Service Provider?' (Speech, UNSW Faculty of Law 40th Anniversary Lecture, 1 December 2012).

143 Justice Melissa Perry, 'iDecide: Administrative Decision-Making in the Digital World' (2017) 91 Australian Law Journal 29, 33. Notably, in 2020 legislation was proposed in Australia to enable automated decision making to be supported by courts: See Australia Social Services and Other Legislation Amendment (Omnibus) Bill 2020 available at <https://www.aph.gov.au/Parliamentary_Business/Bills_Legislation/bd/ bd2021a/21bd003> accessed 18 September 2020.

144 Richard Susskind, Online Courts and the Future of Justice (Oxford University Press, 2019) 43.

${ }_{145}$ Richard Susskind, Online Courts and the Future of Justice (Oxford University Press, 2019) 44.

146 Richard Susskind, Online Courts and the Future of Justice (Oxford University Press, 2019) 44-45.

147 Richard Susskind, Online Courts and the Future of Justice (Oxford University Press, 2019) 43. 
pyramid model will shift to a streamlined 'rocket' model as the routine work previously performed by junior lawyers is automated. At the industry level, Menon notes that law firms will no longer claim a monopoly over the delivery of legal services as technology allows a host of alternative legal service providers to enter the market;

(iii) Third, technology challenges the fundamental values and ethics of the legal profession. As an increasing number of non-law actors play a role in the legal industry, questions arise as to whether such actors should be required to identify with the values and ideals underpinning the legal profession; and

(iv) Finally, Menon argues that technology raises questions when it comes to safeguarding the sound development of the law. His Honour notes that the 'inscrutable nature of the underlying algorithm', the potential for stereotyping and bias in outcomes, and the challenges posed by ODR mechanisms which divert cases away from the court raises issues for the continuing development of the law. ${ }^{148}$

\section{ACCESS TO JUSTICE, COURTS AND JUDGES}

There is other extensive judicial commentary about the use of technology in the justice sphere that is discussed in greater detail throughout this book. Yet despite the contention that exists here, there is widespread agreement among the legal community that technology can assist in upholding core principles of access to justice. Indeed, judges in Australia, ${ }^{149}$ the United Kingdom ${ }^{150}$ and the United States, ${ }^{151}$ have reflected on the access to justice benefits associated with the digitization of court processes (see also Chapter 6).

In 2019 it was estimated that more than 1.5 billion people around the world were unable to access a justice system to assist them in dealing with a legal

148 Chief Justice Sundaresh Menon, 'Deep Thinking: The Future of the Legal Profession in an Age of Technology' (Speech, 29th Inter-Pacific Bar Association Annual Meeting and Conference, Raffles City Convention Centre, Singapore, 25 April 2019).

149 Justice Melissa Perry, 'iDecide: Administrative Decision-Making in the Digital World' (2017) 91 Australian Law Journal 29, 34. See also Australia Social Services and Other Legislation Amendment (Omnibus) Bill 2020 available at $<$ https://www.aph .gov.au/Parliamentary_Business/Bills_Legislation/bd/bd2021a/21bd003> accessed 18 September 2020.

150 Lord Hodge, 'Law and Technological Change' (Speech, British Irish Commercial Bar Association, Edinburgh, 4 April 2019) [9].

151 Justice Deno Himonas, 'Utah's Online Dispute Resolution Program' (2018) 122(3) Dickinson Law Review 875, 880-881. 
issue, and often those who were unable to access the justice system were the most marginalized members of the community. ${ }^{152}$ In this respect, access to justice issues are not new. However, such issues have been exacerbated by the impacts of the 2020 global pandemic and have ultimately caused a re-evaluation of how technology may be deployed to address the access to justice crisis. Steven et al. explain:

Now as well as before the pandemic, marginalised communities - already poorly served by justice systems - face the highest risks, as do vulnerable groups. The pandemic is widening the justice gap, with a sharp increase in the problems that many people face and the ability of justice actors to respond declining. ${ }^{153}$

However, in terms of access to justice, it would be too narrow a view to say that access to 'justice' equates to access to courts and court processes. As the author has previously noted, in recent years there have been significant changes in terms of how broadly justice is defined (see the discussion in Chapter 6). ${ }^{154}$ Galanter, for example, has noted that "just as health is not found primarily in hospitals or knowledge in schools, so justice is not primarily to be found in official justice-dispensing institutions'. ${ }^{155}$ In other words, as the author has previously noted, 'justice resides outside as well as within courts' ${ }^{156}$ In a 2009 report, the Australian Access to Justice Taskforce explained that this broader view of justice 'means giving people choice and providing the appropriate forum for each dispute, but also facilitating a culture in which fewer disputes need to be resolved' (see the more extensive discussion in Chapter 6). ${ }^{157}$

152 David Steven, Maaike de Langen, Sam Muller and Mark Weston, Justice for All and the Public Health Emergency (Justice in a Pandemic - Briefing One, April 2020) 2.

153 David Steven, Maaike de Langen, Sam Muller and Mark Weston, Justice for All and the Public Health Emergency (Justice in a Pandemic - Briefing One, April 2020) 2.

154 Tania Sourdin, 'Civil Dispute Resolution Obligations: What is Reasonable?' (2012) 35(5) UNSW Law Journal 889, 893.

${ }_{155}$ M Galanter, 'Justice in Many Rooms' in M Cappelletti (ed), Access to Justice and the Welfare State (Sijthoff and Noordhoff, Alphen aan den Rijn, 1981) 161.

156 Tania Sourdin, 'Civil Dispute Resolution Obligations: What is Reasonable?' (2012) 35(5) UNSW Law Journal 889, 892.

157 Access to Justice Taskforce, A Strategic Framework for Access to Justice in the Federal Civil Justice System (Report, Attorney-General's Department, Commonwealth of Australia, Canberra, September 2009) 4. This material is also drawn and discussed in more detail in: Tania Sourdin, 'Civil Dispute Resolution Obligations: What is Reasonable?' (2012) 35(5) UNSW Law Journal 889; Tania Sourdin, 'A Broader View of Justice' in Michael Legg (ed), The Future of Dispute Resolution (LexisNexis, 2012). 
In many ways, this broader view of justice ${ }^{158}$ and the acknowledgement that courts are not always an 'appropriate forum' for dispute resolution has paved the way for ODR processes that exist outside courts which are integrated within the justice system. As noted above, jurisdictions are now including ODR processes such as online mediation, online case appraisal and online arbitration or adjudication into their dispute resolution domain. ${ }^{159} \mathrm{By}$ incorporating these and also newer AI-based ODR developments, ${ }^{160}$ justice systems are 'moving towards supporting resolution via technological means' ${ }^{161}$ and ultimately substantiating the notion that access to justice does not depend on physical location. ${ }^{162}$ This elimination of geographical proximity is of particular benefit in the context of the 2020 global pandemic. However, there are ongoing issues relating to the location of non-physical ODR activities. In some jurisdictions, these might be supervised by judges and courts and in others, such activities may be completely independent from courts. These approaches are discussed in some detail in Chapters 6 and 7 of this book with particular reference to e-justice portals and also online courts.

It is clear that increased access to the internet has enabled ODR processes to be embraced by jurisdictions in their bid to increase access to justice. However, literature exists that suggests disseminating justice by online means may actually hinder access to justice for some. In this regard, it is often assumed that as internet use increases, individuals will be able to access dispute resolution options online. Yet, for many people, this is not the case. Cashman and Ginnivan explain that the efficiency of ODR 'relies on parties having both digital access (access to a working internet connection) and digital ability (the ability to use the internet to navigate an online platform) ${ }^{\prime} .{ }^{163}$ In this

158 This is discussed in more detail in Tania Sourdin, 'A Broader View of Justice' in Michael Legg (ed), Resolving Civil Disputes (LexisNexis, Australia, 2016).

159 Tania Sourdin and Chinthaka Liyanage, 'The Promise and Reality of Online Dispute Resolution in Australia' in Mohamed S Abdel Wahab, Ethan Katsh and Daniel Rainey (eds), Online Dispute Resolution: Theory and Practice: A Treatise on Technology and Dispute Resolution (Eleven International Publishing, 2012) 483, 484.

160 Tania Sourdin and Chinthaka Liyanage, 'The Promise and Reality of Online Dispute Resolution in Australia' in Mohamed S Abdel Wahab, Ethan Katsh and Daniel Rainey (eds), Online Dispute Resolution: Theory and Practice: A Treatise on Technology and Dispute Resolution (Eleven International Publishing, 2012) 483, 484.

161 Tania Sourdin, 'A Broader View of Justice' in Michael Legg (ed), Resolving Civil Disputes (LexisNexis, 2016) 19-36.

162 Peter Cashman and Eliza Ginnivan, 'Digital Justice: Online Resolution of Minor Civil Disputes and the Use of Digital Technology in Complex Litigation and Class Actions' (2019) 19 Macquarie Law Journal 39, 52.

163 Peter Cashman and Eliza Ginnivan, 'Digital Justice: Online Resolution of Minor Civil Disputes and the Use of Digital Technology in Complex Litigation and Class Actions' (2019) 19 Macquarie Law Journal 39, 54. 
sense, as the author together with $\mathrm{Li}$ and Burke explain, a 'digital divide' exists among the community. ${ }^{164} \mathrm{Cabral}$ et al. further state that, due to this digital divide, ODR systems may be 'incapable of delivering appropriate justice to low-income persons' ${ }^{165}$ One solution posited by Steven et al. is to encourage donors to fund and partner with 'intermediaries who support the development and dissemination of open source apps and platforms that can be rapidly deployed by civil society actors'. ${ }^{166}$ This is an interesting proposition pertaining to issues surrounding the digital divide, which is discussed in Chapter 6 of this book.

The ways in which newer technologies can enhance access to justice raise a number of issues that are relevant to the judicial role of the future. First, there are questions about how dispute resolution activities are related to the work of courts and judges. That is, the future structure of the justice system may be conceived of in a 'centralist' way where a court is the critical centre of justice and fosters ODR and other activities. Alternatively, a court and judges may be considered to be critical components in terms of justice and 'e-justice' systems that are enabled by newer technologies, and this can mean that courts become less relevant as ODR systems are increasingly established outside courts (see Chapter 10). Each option results in striking jurisdictional variation. There are related questions about what a court is and the extent to which it is independent that can be linked to technological change, with some commentators suggesting that 'non-judicial' activities could be supervised, managed and developed in a 'court' by the executive arm of government (see Chapter 7).

Second, the impact on litigants of either 'supportive Judge AI' (see Chapter 5) or 'Judge AI (Chapter 8) can be extensive in terms of access to justice. Some commentators have referred to somewhat dystopian outcomes that include a loss of judicial independence and negative impacts on democratic society (Chapter 7), the promotion of unfair outcomes and the dehumanization of the law. Others have pointed to the benefits of artificial 'judicial' decision making with potentially cheaper, faster and more accurate determinations.

Access to justice is also informed by 'access to data' developments, with significant jurisdictional differences that will be enlarged in the coming years

164 Tania Sourdin, Bin Li and Tony Burke, 'Just, Quick and Cheap? Civil Dispute Resolution and Technology' (2019) 19 Macquarie Law Journal 17, 32.

165 James E Cabral, Abhijeet Chavan, Thomas M. Clarke, John Greacen, Bonnie Rose Hough, Linda Rexer, Jane Ribadeneyra and Richard Zorza, 'Using Technology to Enhance Access to Justice' (2012) 26(1) Harvard Journal of Law \& Technology 241, 265.

166 David Steven, Maaike de Langen, Sam Muller and Mark Weston, 'Justice for All and the Public Health Emergency' (Justice in a Pandemic - Briefing One, April 2020) 20 . 
as supportive Judge AI and Judge AI developments become more relevant over the next decade. 'Open access' arrangements may ${ }^{167}$ for example, enable more people to better understand court processes and outcomes, invite greater public scrutiny of the judicial role and also foster judicial concern about how such data might be interpreted and used. ${ }^{168}$

However, in relation to these arrangements, it is often assumed that judges only adjudicate and that developments in machine learning and predictive technologies that can be supported by greater access to data, will result in a decline in the number of judges. Much commentary appears to assume that this is the case and suggests that supportive and Judge AI will result in the replacement of human judges. However, apart from the many questions about the extent to which this is currently feasible or desirable, as the next chapter demonstrates, it is incorrect to assume that the decision-making function is the only function undertaken by judges.

167 See 'Making Chinese Court Filings Public? Some Not-So-Foreign American Insights' (2020) 113 Harvard Law Review 1728.

168 Jena McGill and Amy Salyzyn, 'Judging by Numbers: How Will Judicial Analytics Impact the Justice System and its Stakeholders?' (2021) 44(1) Dalhousie Law Journal (forthcoming). 